\title{
The effects of schooling incentive programs on household resource allocation in Bangladesh
}

Mary Arends-Kuenning

Sajeda Amin

Population Council

Follow this and additional works at: https://knowledgecommons.popcouncil.org/departments_sbsr-pgy

Part of the Demography, Population, and Ecology Commons, and the Educational Sociology Commons How does access to this work benefit you? Let us know!

\section{Recommended Citation}

Arends-Kuenning, Mary and Sajeda Amin. 2000. "The effects of schooling incentive programs on household resource allocation in Bangladesh," Policy Research Division Working Paper no. 133. New York: Population Council. 


\section{The Effects of Schooling Incentive Programs on H ousehold Resource Allocation in Bangladesh}

$M$ ary Arends-Kuenning

Sajeda Amin

2000 No. 133 


\title{
The Effects of Schooling Incentive Programs on Household Resource Allocation in Bangladesh
}

\author{
Mary Arends-Kuenning \\ Sajeda Amin
}

Mary Arends-Kuenning is a doctoral candidate, University of Illinois. Sajeda Amin is Associate, Policy Research Division, Population Council, New York. An earlier version of this paper was presented at the Annual Meeting of the Population Association of America, Chicago, IL, April 1998. Deborah Levison and Cynthia Lloyd provided helpful comments. 


\begin{abstract}
This paper examines the impact of programs that provide incentives for school attendance in rural Bangladesh - a food-for-education program for poor primaryschool children and a secondary-school scholarship scheme for girls. Detailed timeuse data were available from a 1991-92 village study conducted prior to the programs' implementation as well as for two points in time in 1995 and 1996 when the programs were in place. The time children spent in school increased dramatically, especially for adolescent girls. Families were able to take advantage of the school programs because of the short school days required and because of the compatibility of household work with schooling. Data from 1992 and 1995 show that a sudden increase occurred in marriage postponement for adolescent girls, because the secondary-school scholarship program required parents to sign a bond assuring that their daughters would not be married before age 18. The effects of the incentives varied by gender. Adolescent boys were less likely to remain in school and more likely to leave to do wage work. Parents may have decided to send adolescent girls to school and adolescent boys to work in response to the incentives.
\end{abstract}

This material may not be reproduced without written permission from the authors. 
In Bangladesh, the transition to mass education for girls began recently and the current generation of girls is the first to attend school in significant numbers. As recently as 1996, the literacy rate for women aged 15 and older in Bangladesh was only 26 percent (UNDP 1998). Historically, enrollment rates have been higher for boys than for girls. Donors and nongovernmental organizations have recently emphasized the importance of women's education for development, and a number of programs have been implemented to increase girls' school attendance. The programs provide financial incentives that are targeted to the poor and to girls. As a result of the incentives, school enrollment has increased dramatically. To give one example, a village study by Amin and Sedgh (1998) found that enrollment rates for girls aged six to 19 increased from 48 percent in 1992 to 71 percent in 1996.

The incentive schemes were motivated by the assumption that financial constraints are the major impediment to schooling: The direct costs of schooling such as fees and books are prohibitive for poor parents, and children's labor contribution is crucial for families' sustenance. The schooling incentive programs minimize the direct costs of schooling by eliminating fees and providing free books. The programs also compensate parents for the indirect costs of schooling, specifically, their children's forgone labor. Children contribute to the household economy through activities that bring in cash such as agricultural work and wage labor. Children also contribute through providing child care and housework. Because families are paid when their children attend school, the schooling incentive programs cover the indirect costs of forgone child labor as well as the direct schooling costs.

In Bangladesh, parents' decision to send adolescent girls to school is also closely linked to marriage-market decisions. The timing and the quality of daughters' marriages are important considerations. The secondary-school scholarship program pays adolescent girls to attend secondary school and to delay marriage. Parents perceive that daughters with education will marry men who are better providers. Marrying their daughters to educated husbands requires parents to pay a higher dowry, however, so this decision involves a tradeoff.

The monthly schooling incentive payments are equal to the amount children could earn during two to four and a half days of wage labor, at most. In light of Bangladeshi parents' considerations of children's labor and daughters' marriage prospects, why has such a strong response to the schooling incentive programs occurred? To answer this 
question, time-use data collected in two Bangladeshi villages in 1992, 1995, and 1996, and responses to two village censuses collected in 1992 and 1995 are used here. The data were collected before and after the schooling incentive programs started in 1994, providing a natural experiment.

Several consequences of increased school enrollment can be analyzed as well. One such consequence is whether the requirement for girls who receive the scholarship to remain unmarried until age 18 has affected marriage rates in the villages. The time use of children is examined by gender, age group, and educational level to see whether increased time spent in school means less time spent performing agricultural work, housework, and wage work. The extent to which children are able to combine work and schooling is discussed. Throughout the analysis, the focus is on the unintended consequences of the schooling incentive programs on other household members. Are adolescent boys put at a disadvantage when adolescent girls are paid to go to school? Does the increased time that girls spend in school and studying cause other female members of the household such as young daughters-in-law to do more housework in order to take up the slack?

\section{BACKGROUND}

The data for this study were collected in two villages (villages A and B) in Mohanpur thana, Rajshahi District, in northern Bangladesh. ${ }^{1}$ In both villages, agriculture is the principal source of income, but with the area's increasing land impoverishment, reliance on agriculture alone is difficult, and most households have to diversify their earnings sources because they do not own enough land to support themselves. Approximately 70 percent of the households in the two villages own less than half an acre and are functionally landless. Household members can work as wage laborers, performing a combination of agricultural and nonagricultural tasks, or they can engage in petty trade. Formal-sector employment opportunities are practically nonexistent. Agricultural wage work differs from nonagricultural work in one important way-meals given to workers by employers account for more than half the compensation that workers receive for agricultural work, whereas nonagricultural wages are paid in cash only. The local custom regarding the form of payment and provision of meals is gender differ-

entiated. Men are almost always paid in a combination of cash and meals. Women are 
seldom paid in cash or in cooked meals. Instead, women are usually paid in food equivalents, such as uncooked rice, which is called taking food shida, or directly. In data collected over the period 1991 to 1992, the average daily wage (including the value of meals) for boys aged 11 to 19 was about 37 taka and for adult men, about 44 taka. $^{2}$ Women had lower wages, but girls' wages were similar to those for boys, with girls aged 11 to 19 earning about 34 taka a day and adult women earning about 30 taka a day. Few women work for wages, and women have lower wages compared with men. Wages earned by boys and girls tend to be similar, particularly at the youngest ages, when they do similar work. The gender gap widens as boys' and girls' work becomes differentiated. Underemployment is high in the villages, so that even if parents want to send their children to work, opportunities might not be available.

Some poverty-alleviating effects may have occurred, however, when external interventions took place between 1992 and 1996, a period when several national microcredit programs expanded to include these villages. By 1995, 50 percent of the households in the study belonged to a microcredit program focused primarily on women (Amin and Sedgh 1998). One study finds that microcredit programs in Bangladesh increase income, production, and employment, especially in nonfarm activities. Microcredit draws labor out of wage employment and into self-employment, raising rural wages (Khandker et al. 1998). These programs usually have a consciousness-raising component, which potentially can affect decisions about schooling by encouraging more positive attitudes toward education.

\section{The SChooling InCEnTive Programs}

In the Bangladeshi school system, primary school consists of grades one through five and secondary school consists of grades six through ten. Primary school is divided into lower primary grades one and two and upper primary grades three to five. Children are supposed to start school at age six, but often enter school at later ages. Recent data suggest that delayed entry is more often the reason for poor grade-for-age performance, but grade repetition is also prevalent. School is in session year round, with one-monthlong summer and winter vacations in July and December. Thus school is in session in the two months included in this study, May and August. 
In 1994, several school-based programs were introduced in the villages. Because neither village had any schooling incentive programs when they were first studied in 1992, data from that period can serve as a baseline. In 1994, village B was chosen for the government food-for-education program. This program is restricted to poor children, who are chosen on the basis of family landholding and occupational criteria. Parents receive 15 kilograms of wheat if their primary-school-aged girls and boys attend school on 85 percent of the days that school is in session. At the time of this study, families could receive only one payment of wheat per month, regardless of how many of their children were in school. The wheat payment equalled US\$2-\$4 in value per month depending on the season-that is, approximately 7 percent of the average monthly family income in these villages. ${ }^{3}$ Children would have to work between two to four and a half days a month to earn the equivalent value of the wheat, provided that they could find work.

In addition, villages A and B participated in the program for secondary-school scholarships for girls, which started in 1994. This incentive consists of monthly stipends deposited in a girl's bank account if she attends secondary school on 65 percent of the days that school is in session and maintains a passing grade-point average from the previous year. The stipend ranges from $\$ 1-\$ 2$ per month, depending on the grade level. In 1994, only girls enrolled in grades six and nine were eligible to enter the program. The program was expanded to include girls in grades seven and eight starting in 1996. As noted above, parents of girls in the program are required to sign an agreement that their daughters will not be married before reaching 18 years of age. A major intention of the government in instituting this program was to raise girls' low median age of marriage -15 years, according to a recent survey (Mitra et al. 1997). ${ }^{4}$

In village $\mathrm{A}$, a large, national nongovernmental organization, the Bangladesh $\mathrm{Ru}-$ ral Advancement Committee (BRAC), opened two primary schools covering first and second grades in 1993 and 1994. In village B, two schools following the BRAC model were started in 1996. By 1996, BRAC schools enrolled 22 percent of first-graders, 28 percent of second-graders, and a total of 8 percent of all six-to-19-year-old children attending school. Using rudimentary supplies, BRAC schools focus on girls and children of the poor. ${ }^{5}$ Class size averages 30 students, with 70 percent of students being girls. The teachers have at least an eighth-grade education; they are trained intensively 
by BRAC and usually come from the same villages as their students. BRAC schools feature short hours of instruction (usually three hours a day) and a schedule that is adjusted seasonally for agricultural work. Books and stationery are provided free to students.

\section{DIRECT AND INDIRECT COSTS OF SCHOOLING}

All of the schooling incentive programs are designed to surmount the financial difficulties that parents face in sending their children to school. The direct costs of attending school include fees, the purchase of books, notebooks, and children's clothing. At the primary-school level, books are provided free in the government schools. Small examination fees and activities fees are collected at the beginning of the term. Figure 1 shows that school fees increase as grade level increases, with fees for eleventh and twelfth grades being especially high. All amounts are shown for 1996 and are given in taka; to give perspective, the value of the 15 kilograms of wheat provided to parents by the food-for-education program varies from around 82.5 taka to 150 taka, depending on the season. The timing of the payment of these fees may provide a hardship for families

Figure 1 Yearly school expenditures for children, by grade level, Bangladesh, 1996

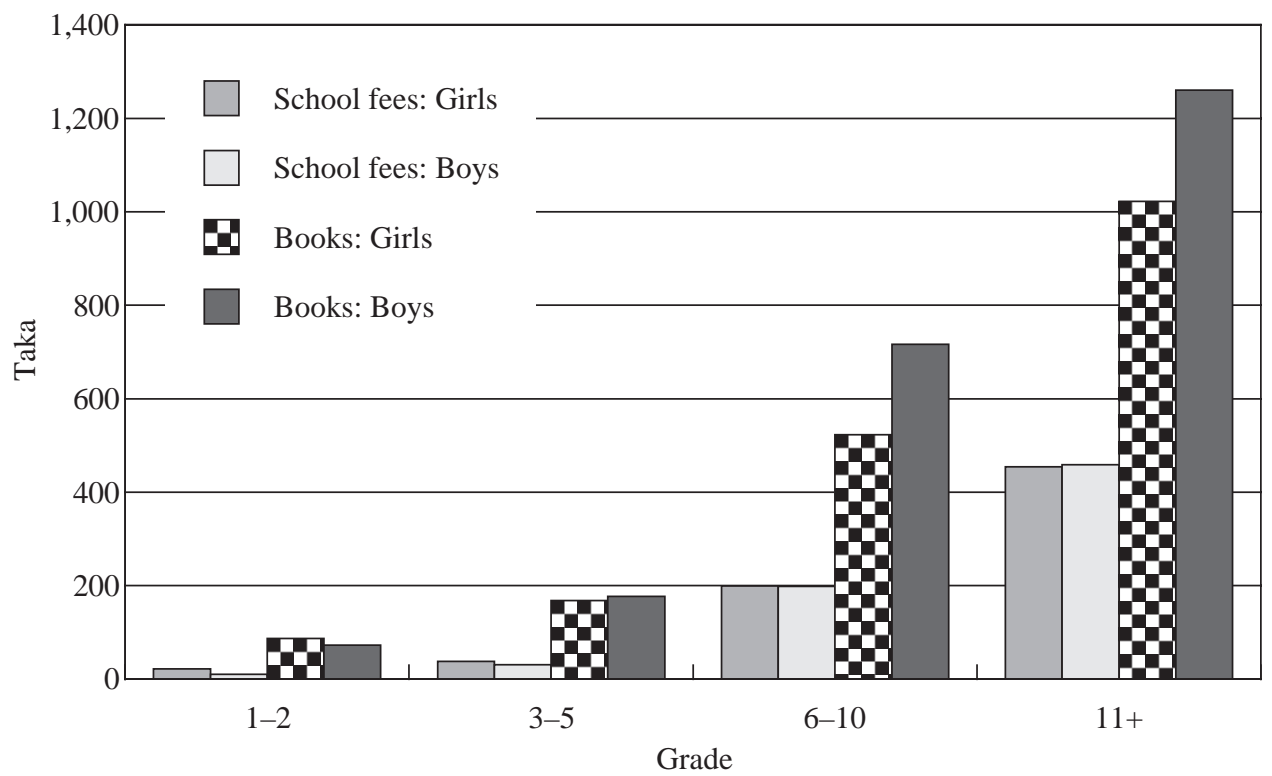


because they occur before the harvest. BRAC schools charge no fees. In villages A and $\mathrm{B}$, sending boys to secondary school required payment of monthly fees and examination fees. As a result of the secondary-school scholarship program for girls, the fees were waived for girls. ${ }^{6}$ Relative to girls, boys faced two obstacles to attending secondary school: Boys had to pay fees and they did not receive the scholarship stipends. Books cost more than school fees, and parents report spending more money on books for boys than they do for girls. In grades six to ten, expenditures on books for boys were 37 percent higher in 1996 than they were on those for girls. ${ }^{7}$

Less obvious than these direct fees are the costs of children's clothing. At the secondary-school level, schools have dress codes and uniforms. Parents may feel ashamed to send their children to school in clothing that is old and torn. Clothing expenses are high relative to those for school fees and books. Amin and Sedgh (1998) found higher total expenses for children in school compared with children at home, and the gap in expenditures rose as children grew older. ${ }^{8}$ Additional schooling expenses were also larger for boys than for girls, so that parents spend more to send boys than girls to school.

In addition to the direct costs of sending their children to school, parents face opportunity costs when children provide household labor. Programs pay parents to send children to school, in addition to waiving fees and providing free books, in effect reimbursing parents for children's reduced household labor contribution. The economic theory of household time allocation stems from Becker (1965). Becker's insight was that demand for goods depends on the time necessary to consume them as well as on their prices. This insight is relevant for studying investments in children's schooling (especially in developing countries), because the time cost to attend school and to study can be high, and the relative opportunity cost of children's time is higher in a country like Bangladesh, compared with the United States. In Bangladesh, the household decision about how to allocate time is complicated by considerations of daughters' marriage prospects and the need for girls' families to pay large dowries to families of their sons-in-law.

\section{DATA}

Time-use data were collected in 1992 from a sample of 240 households, containing a total of 890 individuals. The 240 households consisted of a 25 percent random 
sample of male-headed households and all of the female-headed households in two villages. The data are longitudinal; the sample was drawn in 1992, and respondents were reinterviewed in 1995 and 1996. In 1995 and 1996, 18 more households were included, for a total of 948 individuals. The number of households and individuals increased because of household division and because women married into the sample families. Each household member older than five contributed observations and was asked to recall sequentially all activities conducted in the 24-hour period prior to the interview. Activities were recorded in daily charts and coded according to a detailed activity list. In 1992, time-use data were collected every 15 days for the first six months and thereafter every 30 days for another six months for a total of 18 rounds of data. ${ }^{9}$ For 1992, only the data collected in May and August are used in the analysis so that they can be compared with the data from 1995 and 1996.

One round of time-use data was collected in August 1995 and another round in May 1996. Table 1 shows time-use observations of five adolescent girls in 1995. The surveys were collected on different days of the week, including days when school is not in session. For example, Banu (column 2) and Aisha (column 3) regularly attend school, but on the day that the time-use data were collected, neither one attended school. Both girls recorded some time studying. The dates of the later surveys were chosen to cover a peak season (May) and a low season (August) for agricultural labor demand and months when school is in session. Therefore, August 1992 can be compared with August 1995 and May 1992 with May 1996. By having data from both 1995 and 1996, one can see how time allocation changes in response to the agricultural season and can examine an additional year of households' adaptation to the schooling incentive programs.

The data for this analysis come from a study designed to explore aggregate-level changes in the sexual division of labor as it is affected by family and gender. The study replicates the design of a village study conducted by Cain in the mid-1970s elsewhere in rural Bangladesh (Cain 1977). The sample size and oversampling of female-headed households is part of the original study design. It presents some important constraints to the methods used in the present analysis. First, restricting analysis to households with schoolaged children stratified by socioeconomic status is appropriate for some questions of interest, but such restrictions yield too few observations for meaningful analysis. Sec- 


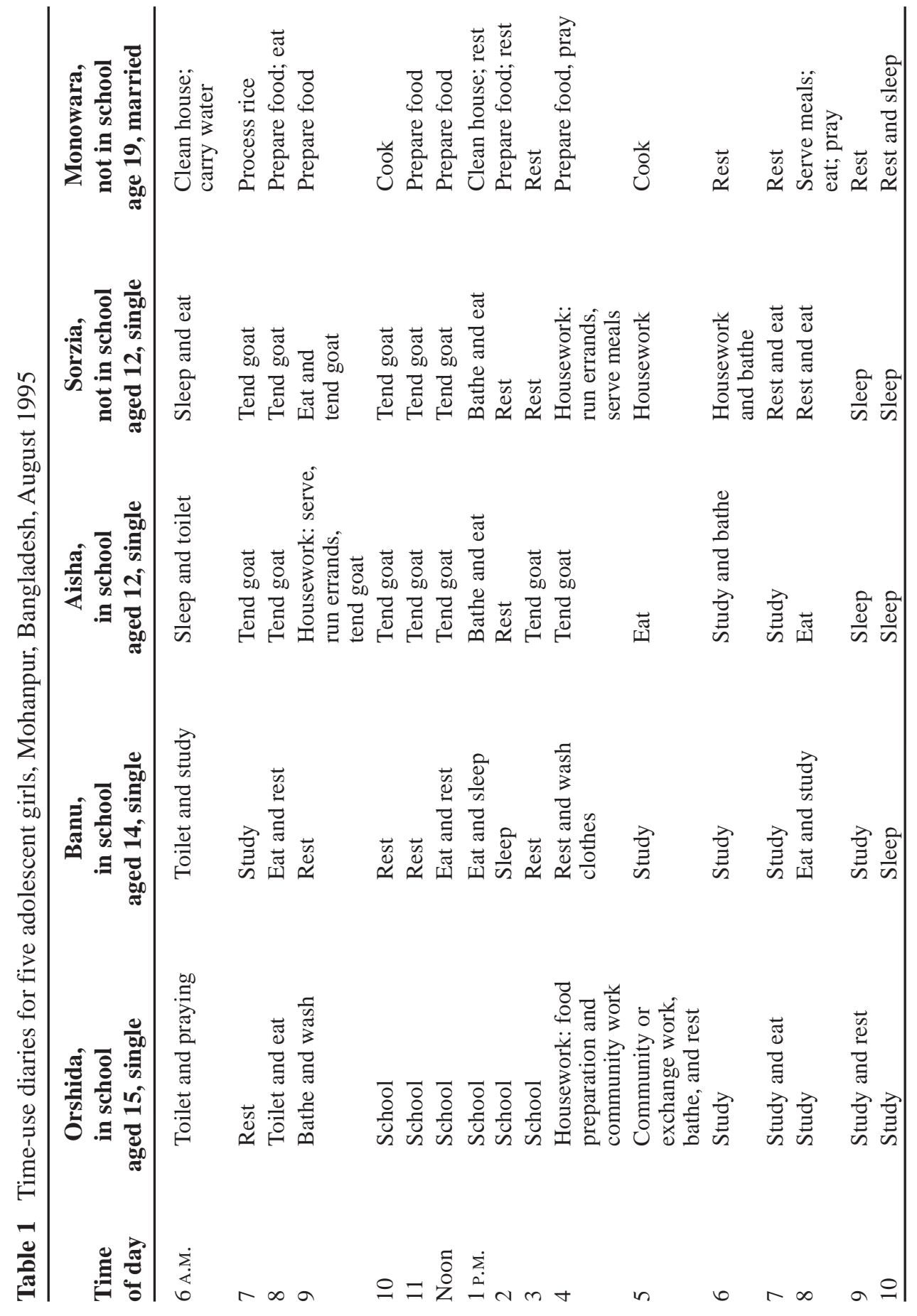


ond, the study villages varied in the education programs available, but stratifying by village would have resulted in inadequate sample sizes in the categories of interest.

The children are grouped by age: six- to ten-year-olds and 11- to 19-year-olds. The adolescent age group covers a wide range because of problems with age heaping. Parents tend to report girls who are aged 13 to 15 as younger if they are not yet married and as older if they are married. Age heaping occurs when a disproportionate number of children are reported to be a certain age compared with the numbers for children of adjacent ages. For girls, age heaping occurs at ages nine and 16, whereas age troughs occur at ages 14 and 17. For boys, age heaping occurs at ages 12 and 16 and age troughs at ages 11,14 , and 17 . The age group 11 to 19 was chosen to include the peaks and the corresponding troughs.

In addition to the time-use data, two complete censuses of the villages were conducted in 1992 and in 1995. The census data are used to compute marriage rates for the village population, to construct sampling weights for the time-use data, and to examine the attrition rates of the individuals included in the original 1992 time-use sample.

More details about the time-use data collection are included in the Appendix.

\section{METHODOLOGY}

In this study, the approach to the data is descriptive-comparing outcomes before the schooling incentive program was in place with outcomes after the program was successfully implemented. The village data describe a natural experiment. The schooling incentive programs were started in 1994, after the May and August rounds of data collection in 1992. The programs were national in scope, and no evidence suggests that the study villages were included because of a perceived high demand there for schooling.

Although the time-allocation data are longitudinal, they are treated here as a series of cross-sections. Longitudinal data appear to be ideal for examining how individual children respond to the schooling incentive programs. With longitudinal data, the researcher can control for unobservable family and individual characteristics that may affect schooling as well as for other independent variables. The problem in this case with using the longitudinal data is sample attrition. Young adults aged 15 to 24 are likely to leave the household to marry, if they are girls, or to emigrate to find work, if they are boys. Limiting the analysis to observations from individuals in both periods would bias 
the results, because the young adults who stay in the village are different on both observable and unobservable characteristics from the young adults who leave. The differences would make those who stay more likely to be enrolled in school than those who leave. Therefore, observations are used from all of the young adults who were present in the sample household at the specified time regardless of whether they were present at other times. The unit of data collection is the household, so that young women who marry into the household are included in subsequent data collection. When households split, both households are followed. Because in-migration and out-migration of entire households are rare in these villages, following the same households should keep the sample approximately random over time.

To complete the data collection for the entire sample within a two-week period, time-allocation data were recorded for the same 24-hour period for the entire household with no provision for return visits. Observations of absences are excluded from the subsequent analysis. Consequently, the average number of hours boys and girls spent in school is likely to be overstated, compared with results that would be obtained if the researcher were to collect data on all children aged 19 or younger who were born in the village, regardless of where the children were living at the time of data collection. For girls, the main reason for being recorded as absent in the data is that they left the village to be married. For boys, absences probably indicate that they were engaged in wage work outside of the village. Therefore, the average number of hours that boys spend performing wage work is likely to be biased downward. A complete discussion of how absences may have affected results is found in the Appendix. By concentrating on the changes in time allocation that occurred after the school incentive programs started, the problem of absences is minimized. If the pattern of people's absences did not change over time, the difference in average hours spent in schooling should be unbiased.

To examine how increases in children's schooling affected the time use of other household members, it is helpful to recall two of Becker's insights about household time allocation. The first is that each member's time allocation depends on that of all other household members; all members' time-allocation decisions are made simultaneously. Therefore, we cannot simply regress an adult family member's time spent in housework, for example, on the time that a child spends on school work. ${ }^{10}$ Because household 
members' time-allocation decisions are practically impossible to disentangle using standard econometric modeling, we opt for a simple descriptive approach. The approach is similar to that taken by Tiefenthaler (1997), who examined how the birth of a child affected household time allocation in the Philippines by comparing the time use of household members before and after the birth.

Becker's second insight of relevance here is that the models do not give clear theoretical predictions about how changes in prices and wages affect time-allocation decisions. Even with only two actors, a husband and wife, most price effects are ambiguous. Incorporating children into the model only complicates matters further. ${ }^{11}$

Becker argues that if the wage of one household member increases, that member will spend more hours in the labor market and fewer hours consuming goods that people require time to enjoy. Other household members will shift their time allocation to timeintensive consumption. Therefore, the increased wage of one household member could increase the time other members spend at school. Likewise, if the cost of schooling decreases for adolescent girls, and schooling is a time-intensive consumption good, then their brothers may spend more time in the labor market.

\section{RESULTS}

Table 2 shows the proportion of girls and boys aged 11 to 19 who were ever married, based on the 1992 and 1995 censuses. ${ }^{12}$ In a short period of time, the programs have decreased marriage rates for adolescent girls from 36 percent to 32 percent. The effect of the schooling incentive programs on marriage rates stems from the requirement that parents sign a bond promising that their daughters will not marry before age 18 .

Table 2 Percentage of boys and girls aged 11-19 who were ever married, Bangladesh, 1992 and 1995

\begin{tabular}{lccccc}
\hline & \multicolumn{2}{c}{ Girls } & & \multicolumn{2}{c}{ Boys } \\
\cline { 2 - 3 } Measure & $\mathbf{1 9 9 2}$ census & $\mathbf{1 9 9 5}$ census & & $\mathbf{1 9 9 2}$ census & $\mathbf{1 9 9 5}$ census \\
\hline Percent & 35.6 & 31.7 & & 3.4 & 3.9 \\
$(\mathrm{~N})$ & $(432)$ & $(429)$ & & $(435)$ & $(459)$ \\
\hline
\end{tabular}


Although few girls already had enough education to take advantage of the secondaryschool scholarships, the prospects of obtaining them in the future delayed marriages.

Table 3 presents data from the 1992 and 1995 censuses pertaining to girls' secondary schooling. The proportion of girls aged 11 to 19 who had completed fifth grade increased from 22 percent to 36 percent between 1992 and 1995. The proportion of these primary-school graduates who opted to continue to secondary school also increased from 48 percent to 62 percent. In 1996 (the only year for which data are available), 69 percent of the girls aged 11 to 19 who were enrolled in secondary school received the scholarship. The proportion of girls aged 11 to 19 who are enrolled in secondary school remains small, at 22 percent, however. The increase in secondary-school enrollments may reflect primarily the enrollment of girls in their early rather than late teens. Because few older adolescent girls have completed primary school, they are not eligible to enroll in secondary school, and parents are not willing to delay their marriages for the years required to finish primary school. Secondary-school enrollments should increase as a higher proportion of adolescent girls complete primary school. Eventually the program will have difficulty increasing secondary-school enrollments for adolescent girls, however, unless parents can be persuaded to postpone their daughters' marriages.

The following statement from a 25 -year-old man, the father of a two-year-old daughter, illustrates how the decision to educate a daughter is tied closely to the marriage decision:

Table 3 Secondary-school continuation rates for adolescent girls, Bangladesh, 1992 and 1995

\begin{tabular}{|c|c|c|c|c|}
\hline \multirow{2}{*}{$\begin{array}{l}\text { Adolescent girls } \\
\text { Number completing fifth grade } \\
\text { (primary school) (as a proportion of } \\
\text { all girls in age group) }\end{array}$} & \multicolumn{2}{|c|}{1992} & \multicolumn{2}{|c|}{1995} \\
\hline & 93 & $(22 \%)$ & 153 & $(36 \%)$ \\
\hline $\begin{array}{l}\text { Number of primary-school graduates } \\
\text { enrolled in secondary school (as a } \\
\text { proportion of primary-school graduates) }\end{array}$ & 45 & $(48 \%)$ & 95 & $(62 \%)$ \\
\hline $\begin{array}{l}\text { Number of primary-school graduates } \\
\text { enrolled in secondary school (as a } \\
\text { proportion of all girls in age group) }\end{array}$ & 45 & $(10 \%)$ & 95 & $(22 \%)$ \\
\hline Girls aged $11-19(\mathrm{~N})$ & & 29) & & 429) \\
\hline
\end{tabular}


Those who are wealthy and have the means should educate their children. Now me, I am poor. If I try to achieve a B.A. for my daughter, then I have to find a provider for her who has an M.A. And these days, they don't come cheap. For example, take Kormokar's son Iftekar-he is a B.A. and he has taken a B.A.-pass wife. He also bought a motorcycle worth 75,000 takas. I have never even seen that kind of money. Suppose I educated my daughter up to [grade 10] — uneducated boys will not come for her out of shame and educated boys will also be expensive. . . . I will keep my daughter in school up to grade four or seven and then marry her off. If there are no good proposals, then she can continue to study.

Parents express ambiguity about the ideal age at which to marry off their daughters. In the following interview, a mother says that her idea of the ideal age for girls to marry is 18 . The government's message to marry daughters at age 18 or older seems to be having an impact. This woman, however, would like her daughter to be married by 15 or 16. She perceives that educating daughters results in a higher dowry demand from prospective husbands.

What do you think is the ideal age at marriage?

Girls at 18 or 19 and boys at 26 years of age.

\section{What is the value of education?}

Isn't being educated good? I have eyes, but I'm still blind. You gain a lot of knowledge. Is it bad being educated? On the other hand, the higher you study, the more money it costs. Also, the costs for getting married increase. When Laili got married, they [her fiancé's family] asked for a Honda [motorcycle].

At what age would you like your children to get married?

My daughter at 15 or 16 and my son at 24 or 25 .

A statement from another mother illustrates two points. First, the secondary-school scholarship stipends may help ease the concerns of parents who do not want to spend 
money that is saved toward a dowry on their daughter's education. Second, the transition from fifth grade to sixth grade is an important turning point, and the design of the scholarship program shows good judgment in focusing on the stipends to sixth-graders. Monetary payments are not sufficient, however. Parents are also concerned with their daughters' reputations. Parents are willing to take only limited risks to send their daughters to a school located some distance away. The woman's husband in this example decided that fifth grade was enough education for his daughter and that the benefits of secondary school were outweighed by the risks. The woman said:

Shadhinara (18) does not go to school anymore. She had completed grade five, and now she is married. After completing grade five, my daughter asked her father to enroll her into the Mohanpur school, but her father did not want to. He said that Mohanpur is too far away, and what would people say if she ventured so far. Or, that she might even acquire a boyfriend! [He said] "she is now grown up, and if proposals start coming, we will get her married. If people start talking, then she has to bear the burden of slander." He also said that a lot more money would have to be spent. My daughter insisted that the money saved up for her marriage should be used instead to pay for her education, but he did not agree. After passing from the primary school, my daughter stayed at home for three years [before she got married], but was not sent to school.

\section{Schooling Time Requirements}

Children in Bangladesh do not require much time to attend school. The school year consists of 220 days. In addition, holidays and lax regulations shorten the school year. Table 4 shows the average hours that girls and boys spend in the classroom on the days that they attend school. First- and second-graders spend less than three hours in the classroom on a typical school day. Time requirements increase with higher grade levels, although the school day is still short. Third-, fourth-, and fifth-graders spend about four hours a day in the classroom, and secondary-school students spend about five hours in 
Table 4 Average number of hours children aged 6-19 report that they spend in the classroom on days they attend school, by grade level and sex, Bangladesh, 1995 and 1996

\begin{tabular}{lccccccccc}
\hline & \multicolumn{3}{c}{ Girls } & & \multicolumn{4}{c}{ Boys } \\
\cline { 2 - 4 } Grades & August 1995 & May 1996 & & August 1995 & May 1996 \\
\hline $1-2(\mathrm{~N})$ & 2.9 & $(22)$ & 2.8 & $(21)$ & & 2.9 & $(21)$ & 2.9 & $(22)$ \\
$3-5(\mathrm{~N})$ & 3.9 & $(29)$ & 4.1 & $(33)$ & & 4.3 & $(33)$ & 4.4 & $(27)$ \\
$6-10(\mathrm{~N})$ & 4.4 & $(7)$ & 5.5 & $(10)$ & & 4.7 & $(4)$ & 5.2 & $(9)$ \\
\hline
\end{tabular}

the classroom. The length of the school day is similar for boys and girls. Comparing 1995 with 1996, the length of the school day did not change for grades one to two and three to five, but both boys and girls in grades six to ten reported longer school days in 1996 than in $1995 .{ }^{13}$ Because the school day is so short, parents might find that schooling does not interfere with their children's other duties and decide that the schooling incentive payments are sufficient to compensate them for the lost labor.

\section{Effects on Children's Time for Schooling}

The time-use data indicate that children spent more time in schooling activities in 1995 and 1996 than they did in 1992. This increase in the time that children devoted to schooling could have occurred by several means including increased enrollment rates, increased time spent in school by those enrolled in school, increased time spent studying by those enrolled in school, and a changing grade distribution. The contribution of each of these factors is considered in turn below. Because the sample size is small, the analysis describes the overall picture rather than its details. Comparisons between May of 1992 and 1996 and between August of 1992 and 1995 show how seasonality affects the time allocated to schooling. Time spent in schooling activities combines the time spent in the classroom with the time spent studying at home to reflect the true time cost of schooling.

In response to the schooling incentives, the average number of hours children spent in schooling activities increased, having different impacts on girls and boys. Table 
5 shows that girls and boys in all age groups reported an increase in the average number of hours they spent on schooling activities. ${ }^{14}$ Looking at the hours for May and August 1992, girls aged six to ten spent more time involved in schooling activities than did boys aged six to ten, whereas boys aged 11 to 19 spent more time involved in schooling activities than did girls aged 11 to 19. In 1995, this pattern was also evident, but in 1996, girls aged six to ten spent less time in schooling activities than did boys aged six to ten, but girls aged 11 to 19 spent more time in schooling activities than did boys aged 11 to 19. Young boys experienced a larger percent change than young girls did in their hours spent on schooling. Because the wheat-allowance-for-education program was not gender specific, parents may have responded by increasing their sons' time spent in school more than their daughters'. The data for girls aged 11 to 19, who would have been most affected by the secondary-school scholarship programs, show large increases in time spent on schooling in 1996. This finding is consistent with results reported by Amin and Sedgh (1998), who found that primary-school completion and subsequent secondaryschool enrollment for girls increased substantially in 1995 and 1996. These data suggest that the primary-schooling incentive programs that were not gender differentiated had larger effects on young boys than on young girls and that the secondary-school programs had larger effects on older girls than on older boys by targeting girls exclusively.

Table 5 Average number of hours children reported that they spent in schooling activities, by age group and sex, Bangladesh, 1992, 1995, and 1996

\begin{tabular}{|c|c|c|c|c|c|c|}
\hline \multirow[b]{2}{*}{ Age } & \multicolumn{3}{|c|}{ Girls } & \multicolumn{3}{|c|}{ Boys } \\
\hline & $\begin{array}{c}\text { August } \\
1992\end{array}$ & $\begin{array}{c}\text { August } \\
1995\end{array}$ & $\begin{array}{l}\text { Percent } \\
\text { change }\end{array}$ & $\begin{array}{c}\text { August } \\
1992\end{array}$ & $\begin{array}{c}\text { August } \\
1995\end{array}$ & $\begin{array}{l}\text { Percent } \\
\text { change }\end{array}$ \\
\hline $6-10(\mathrm{~N})$ & $2.54(51)$ & $3.89(54)$ & 53 & $1.92(56)$ & $3.16 \quad(57)$ & 65 \\
\hline \multirow[t]{2}{*}{$11-19(\mathrm{~N})$} & $2.24(81)$ & $2.93(93)$ & 31 & $2.78(90)$ & $3.32(103)$ & 19 \\
\hline & $\begin{array}{l}\text { May } \\
1992\end{array}$ & $\begin{array}{l}\text { May } \\
1996\end{array}$ & $\begin{array}{l}\text { Percent } \\
\text { change }\end{array}$ & $\begin{array}{l}\text { May } \\
1992\end{array}$ & $\begin{array}{l}\text { May } \\
1996\end{array}$ & $\begin{array}{c}\text { Percent } \\
\text { change }\end{array}$ \\
\hline $6-10(\mathrm{~N})$ & $2.28(52)$ & $2.88(42)$ & 26 & $1.64(59)$ & $3.25 \quad(52)$ & 98 \\
\hline $11-19(\mathrm{~N})$ & $2.05(89)$ & $3.52(96)$ & 72 & $2.21(98)$ & $2.79 \quad(98)$ & 26 \\
\hline
\end{tabular}


Boys aged 11 to 19 showed the smallest increases in the amount of time spent in school and studying. In fact, boys aged 16 to 19 spent 12 minutes less in school in May 1996 than they did in May 1992, and an hour less in school in August 1995 than in August 1992 (results not shown). This finding suggests that at the secondary-school level, parents might be deciding to send older daughters to school and not older sons for two reasons: First, the costs of sending boys to secondary school are greater than those of sending girls. Second, boys can earn a higher income outside of the house than girls can, so the opportunity costs of time for boys are higher than those for girls. The advantages that boys have compared with girls, such as higher parental investment and higher wages in the labor market, might be a disadvantage for boys with respect to access to schooling.

Increased school-enrollment rates, as shown in Table 6, contributed to the increase in time that children spent involved in schooling activities. For all age groups and for both boys and girls, enrollment rates increased when August 1992 is compared with August 1995 and when May 1992 is compared with May 1996. Changes in enrollment were dramatic for boys aged six to ten, the group that would be most affected by the food-for-education program, and for girls aged 11 to 19, the group that would be most affected by the secondary-school scholarship program. Enrollment rates were low for

Table 6 School-enrollment rates, by age group and sex, Bangladesh, 1992, 1995, and 1996

\begin{tabular}{|c|c|c|c|c|c|c|}
\hline \multirow[b]{2}{*}{ Age } & \multicolumn{3}{|c|}{ Girls } & \multicolumn{3}{|c|}{ Boys } \\
\hline & $\begin{array}{c}\text { August } \\
1992\end{array}$ & $\begin{array}{c}\text { August } \\
1995\end{array}$ & $\begin{array}{l}\text { Percent } \\
\text { change }\end{array}$ & $\begin{array}{c}\text { August } \\
1992\end{array}$ & $\begin{array}{c}\text { August } \\
1995\end{array}$ & $\begin{array}{l}\text { Percent } \\
\text { change }\end{array}$ \\
\hline $6-10$ & 0.68 & 0.87 & 28 & 0.46 & 0.71 & 54 \\
\hline \multirow[t]{2}{*}{ 11-19 } & 0.43 & 0.48 & 12 & 0.45 & 0.53 & 18 \\
\hline & $\begin{array}{l}\text { May } \\
1992\end{array}$ & $\begin{array}{l}\text { May } \\
1996\end{array}$ & $\begin{array}{l}\text { Percent } \\
\text { change }\end{array}$ & $\begin{array}{l}\text { May } \\
1992\end{array}$ & $\begin{array}{l}\text { May } \\
1996\end{array}$ & $\begin{array}{l}\text { Percent } \\
\text { change }\end{array}$ \\
\hline $6-10$ & 0.70 & 0.73 & 4 & 0.53 & 0.70 & 32 \\
\hline $11-19$ & 0.42 & 0.59 & 40 & 0.49 & 0.50 & 2 \\
\hline
\end{tabular}

Note: See Table 5 for $(\mathrm{N})$. 
boys aged six to ten in 1992 compared with those for girls. Boys aged 11 to 19 experienced only a 2 percent increase in enrollment rates in 1996 compared with those rates for 1992. Although increases in enrollment rates may explain part of the increase in the number of hours children spent on schooling, other factors such as more regular school attendance also played a part.

Did the time children spent in schooling activities increase because school became a more intensive activity as a result of the incentive programs? Table 7 shows the average time spent in schooling activities by gender and grade level. ${ }^{15}$ Not surprisingly, as the grade level increases, the time spent in the classroom and in studying increases. The amount of time that girls enrolled in secondary school spent on schooling activities did not increase greatly. Although the time spent in the classroom for secondary-school students increased between 1995 and 1996, as shown in Table 4, female students responded by decreasing the amount of time they spent studying at home. For third- to fifth-graders, a clear trend is seen wherein both girls and boys spent at least one hour more on schooling activities in 1995 and 1996 than they did in 1992. Most of this increase was due to an increase in the time spent studying outside the classroom. Perhaps the secondary-school scholarship program encouraged girls to spend more time studying in order to pass primary school and continue to secondary school. Because the program did not apply to boys, the reason for the increase in the time boys spent studying is

Table 7 Average number of hours children spent in school and studying, by grade level and sex, Bangladesh, 1992, 1995, and 1996

\begin{tabular}{|c|c|c|c|c|}
\hline \multirow[b]{2}{*}{ Grade } & \multicolumn{2}{|c|}{ Girls } & \multicolumn{2}{|c|}{ Boys } \\
\hline & August 1992 & August 1995 & August 1992 & August 1995 \\
\hline $1-2(\mathrm{~N})$ & 4.2 (37) & $3.5 \quad(39)$ & 3.7 (24) & $3.4 \quad(42)$ \\
\hline $3-5(\mathrm{~N})$ & $3.8 \quad(25)$ & $5.2(43)$ & $5.5 \quad(23)$ & $6.7 \quad(41)$ \\
\hline $6-10(\mathrm{~N})$ & $7.8 \quad(8)$ & 7.2 (19) & $7.8 \quad(17)$ & $6.7 \quad(27)$ \\
\hline Grade & May 1992 & May 1996 & May 1992 & May 1996 \\
\hline $1-2(\mathrm{~N})$ & $3.4 \quad(39)$ & $3.8 \quad(23)$ & $3.0 \quad(32)$ & 3.9 (19) \\
\hline $3-5(N)$ & $4.6 \quad(26)$ & 5.7 (34) & $3.9 \quad(22)$ & $5.3 \quad(28)$ \\
\hline $6-10(\mathrm{~N})$ & $5.8 \quad(8)$ & $6.1 \quad(19)$ & $5.1 \quad(23)$ & $6.5 \quad(25)$ \\
\hline
\end{tabular}


not clear. Therefore, only for children in grades three to five, whose ages would be approximately eight to 12 , can the increase in the time spent on schooling activities be explained by an increased time required to succeed at a specific grade level.

Children spent more time in schooling activities in August during the season of lessened agricultural labor demand, than they did in May, a month of high agricultural labor demand. Table 5 shows that the time spent in schooling activities was higher in August 1992 than it was in May 1992, except for girls aged 11 to 19. This pattern is also shown in Table 7, which controls for grade level. Except for girls in grades three to five, children spent more time on schooling activities in August 1992 than in May 1992. When comparing 1995 with 1996, the average hours spent in schooling activities were often lower in 1996 than in 1995; part of the difference is due to seasonality. The time that boys in all grades spent on schooling activities was higher in August of 1992 than in May of 1992. Boys are especially affected by seasonality, and their schooling decreases during times of peak labor demand.

Over time, as a result of increased enrollments at the primary-school level, children are more likely to be enrolled in the proper grades for their ages. Because the higher grades require that students spend more time at school and studying than do the lower grades, the time spent on schooling for particular age groups will increase as a higher percentage of children are enrolled at the upper primary and secondary levels. For children aged six to ten, the grade distribution does not change much, so that the hours spent on schooling were increased only slightly by children enrolling at upper primary rather than lower primary levels.

For children aged 11 to 19 , grade distributions changed by a substantial amount (not shown). After the schooling incentives were started, children who attended school were more likely to be enrolled in grades three to ten compared with grades one or two. In 1992, 37 percent of girls aged 11 to 19 who attended school were enrolled in grades one or two, 40 percent were enrolled in grades three to five, and 23 percent were enrolled in grades six to ten. By 1995, only 7 percent were enrolled in grades one or two, 52 percent were enrolled in grades three to five, and 41 percent were enrolled in grades six to ten. A comparison of enrollment for 1992 with that of 1996 for girls aged 11 to 19 reveals the same pattern, although the increase in secondary-school enrollment was less 
dramatic than that shown in the comparison of 1992 and 1995. In 1992, 27 percent of girls aged 11 to 19 who were attending school were enrolled in grades one or two, 49 percent were enrolled in grades three to five, and 24 percent were enrolled in grades six to ten. In 1996, only 9 percent were enrolled in grades one or two, 63 percent were enrolled in grades three to five, and 28 percent were enrolled in grades six to ten. Therefore, the change in grade distribution for girls aged 11 to 19 definitely contributed to the increase in the mean number of hours spent on school activities.

Boys aged 11 to 19 who attended school in 1992 were more likely than girls of the same ages to be enrolled in the higher grades. Their grade distributions did not change as dramatically in response to the schooling incentive programs as did those of girls. The proportion of boys attending school in 1995 and in 1996 who were enrolled in secondary school fell compared with enrollment for 1992. In 1992, based on the figures for August, 18 percent of boys aged 11 to 19 who were attending school were enrolled in grades one or two, 35 percent were enrolled in grades three to five, and 48 percent were enrolled in grades six and higher (not shown). In August 1995, the proportion attending school who were enrolled in grades one or two fell to 7 percent, whereas the proportion enrolled in grades three to five increased to 52 percent, and the percentage enrolled in secondary school and up fell to 41 percent. When the data for May of 1992 are compared with those for May of 1996, the proportion of boys aged 11 to 19 attending school who were enrolled in grades one or two are found to have remained the same at 17 percent, whereas the proportion enrolled in grades three to five are found to have increased from 29 to 50 percent and the proportion enrolled in secondary school and higher to have decreased from 54 percent to 33 percent (not shown). One reason that the schooling of boys aged 11 to 19 lagged behind the schooling for the other gender-age groups is that the boys who were enrolled in school after the schooling incentive programs were put in place were more likely to be enrolled in the lower grades than were the boys who were enrolled in school prior to the start of the incentive programs.

In summary, increases in enrollment, increases in the amount of time students spent on schooling activities, and changes in grade distribution all play a role in explaining the increase in the time that children spent in school. Older girls, especially, experienced increased enrollments and changes in grade distribution from lower to higher grades. Children in grades three to five increased their time spent involved in schooling 
activities, whereas children in other grades did not. A higher proportion of older girls were enrolled in grades three to five in 1995 and 1996 than in 1992. The schooling of older boys lagged behind because enrollments stayed about the same, and the distribution of grades shifted from the highest grades to the middle grades.

\section{Time Children Spend in Work Outside of School}

How did the increase in children's schooling hours affect the amount of time spent at other activities? Table 8 presents the results for the average hours children spent doing agricultural work, housework, and wage work by sex and by age group. Agricultural work performed by children includes collecting fodder and feed for animals, tending cattle, goats, and poultry, clearing land, plowing, sowing, harvesting, marketing farm produce, fishing, hunting, and gathering. Housework includes caring for younger children and elderly relatives, carrying water, cleaning house, washing clothes and dishes, and preparing food. Wage work includes self-employed skilled services, agricultural wage work, daily labor, salaried labor, and looking for wage work. Time spent in carrying agricultural produce to the homestead was included in wage work, and time spent going to and from school was included in school work.

Time spent in agricultural work is declining over time, except for girls aged 11 to 19 in 1995, who spent little time in agricultural work anyway. Older girls spend less time doing agricultural work than do younger girls, because traditionally, younger girls tend animals while older girls do housework. Younger boys show the largest percentage decreases in hours spent in agricultural work, probably because they are spending more time in school. Boys aged 11 to 19 reduced their hours at agricultural work, and instead worked more hours in wage work. The trend is best seen by comparing May 1992 with May 1996, because demand for agricultural labor peaks in May. Some of the increased time children spend in schooling activities is coming from time formerly spent at agricultural work.

Between 1992 and 1995, girls aged 11 to 19 decreased the amount of time they spent doing housework by about 20 minutes a day and by about 40 minutes a day between 1992 and 1996. Girls aged six to ten did more housework after the schooling incentive programs were put in place, spending about half an hour more doing housework in 1995 than in 1992, but doing only about four minutes more in 1996 than in 
Table 8 Average hours children spent performing agricultural work, housework, and wage work, by age group and sex, Bangladesh, August 1992 and 1995, May 1992 and 1996

\begin{tabular}{|c|c|c|c|c|c|c|}
\hline \multirow[t]{3}{*}{ Age } & \multicolumn{3}{|c|}{ Girls } & \multicolumn{3}{|c|}{ Boys } \\
\hline & \multicolumn{6}{|c|}{ Agricultural work } \\
\hline & $\begin{array}{c}\text { August } \\
1992 \\
\end{array}$ & $\begin{array}{c}\text { August } \\
1995\end{array}$ & $\begin{array}{l}\text { Percent } \\
\text { change }\end{array}$ & $\begin{array}{c}\text { August } \\
1992 \\
\end{array}$ & $\begin{array}{c}\text { August } \\
1995\end{array}$ & $\begin{array}{l}\text { Percent } \\
\text { change }\end{array}$ \\
\hline $6-10$ & 1.64 & 0.63 & -62 & 2.18 & 1.52 & -30 \\
\hline \multirow[t]{2}{*}{$11-19$} & 0.84 & 0.91 & 8 & 2.94 & 2.62 & -11 \\
\hline & $\begin{array}{l}\text { May } \\
1992 \\
\end{array}$ & $\begin{array}{l}\text { May } \\
1996 \\
\end{array}$ & $\begin{array}{l}\text { Percent } \\
\text { change }\end{array}$ & $\begin{array}{l}\text { May } \\
1992 \\
\end{array}$ & $\begin{array}{l}\text { May } \\
1996 \\
\end{array}$ & $\begin{array}{l}\text { Percent } \\
\text { change }\end{array}$ \\
\hline $6-10$ & 1.20 & 1.15 & -4 & 2.25 & 1.18 & -48 \\
\hline \multirow[t]{3}{*}{$11-19$} & 0.89 & 0.58 & -35 & 3.52 & 1.96 & -44 \\
\hline & \multicolumn{6}{|c|}{ Housework } \\
\hline & $\begin{array}{c}\text { August } \\
1992 \\
\end{array}$ & $\begin{array}{c}\text { August } \\
1995\end{array}$ & $\begin{array}{l}\text { Percent } \\
\text { change }\end{array}$ & $\begin{array}{c}\text { August } \\
1992 \\
\end{array}$ & $\begin{array}{c}\text { August } \\
1995\end{array}$ & $\begin{array}{l}\text { Percent } \\
\text { change }\end{array}$ \\
\hline $6-10$ & 0.28 & 0.82 & 193 & 0.13 & 0.07 & -46 \\
\hline \multirow[t]{2}{*}{$11-19$} & 3.02 & 2.73 & -10 & 0.19 & 0.06 & -68 \\
\hline & $\begin{array}{l}\text { May } \\
1992 \\
\end{array}$ & $\begin{array}{l}\text { May } \\
1996 \\
\end{array}$ & $\begin{array}{l}\text { Percent } \\
\text { change }\end{array}$ & $\begin{array}{l}\text { May } \\
1992 \\
\end{array}$ & $\begin{array}{l}\text { May } \\
1996 \\
\end{array}$ & $\begin{array}{l}\text { Percent } \\
\text { change }\end{array}$ \\
\hline $6-10$ & 0.55 & 0.62 & 13 & 0.06 & 0.00 & -100 \\
\hline \multirow[t]{3}{*}{$11-19$} & 3.06 & 2.43 & -21 & 0.08 & 0.24 & 200 \\
\hline & \multicolumn{6}{|c|}{ Wage work } \\
\hline & $\begin{array}{c}\text { August } \\
1992 \\
\end{array}$ & $\begin{array}{c}\text { August } \\
1995 \\
\end{array}$ & $\begin{array}{l}\text { Percent } \\
\text { change }\end{array}$ & $\begin{array}{c}\text { August } \\
1992 \\
\end{array}$ & $\begin{array}{c}\text { August } \\
1995 \\
\end{array}$ & $\begin{array}{l}\text { Percent } \\
\text { change }\end{array}$ \\
\hline $6-10$ & 0.00 & 0.01 & - & 0.04 & 0.37 & 825 \\
\hline \multirow[t]{2}{*}{$11-19$} & 0.04 & 0.19 & 375 & 0.53 & 0.86 & 62 \\
\hline & $\begin{array}{l}\text { May } \\
1992 \\
\end{array}$ & $\begin{array}{l}\text { May } \\
1996\end{array}$ & $\begin{array}{l}\text { Percent } \\
\text { change }\end{array}$ & $\begin{array}{l}\text { May } \\
1992 \\
\end{array}$ & $\begin{array}{l}\text { May } \\
1996\end{array}$ & $\begin{array}{l}\text { Percent } \\
\text { change }\end{array}$ \\
\hline $6-10$ & 0.05 & 0.00 & -100 & 0.22 & 0.00 & -100 \\
\hline $11-19$ & 0.17 & 0.10 & -41 & 1.01 & 1.65 & 63 \\
\hline
\end{tabular}

Note: See Table 5 for $(\mathrm{N})$.

$-=$ Not applicable; division by 0 . 
1992. Young girls do not spend much time doing housework compared with their older sisters and sisters-in-law, however. Young married women might bear the costs of increased schooling opportunities for other girls who live in the same household. Young married women might be required to take on increased housework that previously was performed by girls not enrolled in school. This issue is discussed further below.

Boys increased their average hours spent in wage work between August 1992 and August 1995, and boys aged 11 to 19 increased their hours spent in wage work by 63 percent between May 1992 and May 1996. As noted above, girls do not do much wage work. Children spend more time in wage work in May than in August, again reflecting the seasonality of wage work, which is primarily agricultural. This increase in adolescent boys' wage work could reflect a response to the incentives households experienced to send adolescent girls to school. Also it may reflect a response to the growth of microcredit programs, because wage work includes self-employed labor.

\section{Gender Differences}

If households chose to send only one adolescent girl or boy to school, the price incentives favored the girls, because girls attending secondary school received stipends, paid no fees, and received free books. If boys are not in school, parents may as well send them to work to earn income. To determine whether the incentives targeted to adolescent girls affected adolescent boys' time allocation, however, we need to consider whether adolescent boys' time spent in wage work might have increased in response to an increase in the wage for daily labor. The data-collection team did not find evidence of an increase in the daily laborers' wages. This issue is discussed further below in a consideration of changes in the time adult men spent in wage work.

Additional evidence that parents favor adolescent girls over adolescent boys in making schooling decisions is presented in Table 9, which presents odds ratios for a logistic regression. The dependent variable is equal to one if the child spent any time in school activities, and the independent variables represent the number of people in the household who share certain demographic characteristics. In 1992, the probability that a boy aged 11 to 19 reported any time in schooling activities was not significantly affected by the number of his sisters aged six to ten and aged 11 to 19 , but by 1995, each addi- 
Table 9 Odds ratios from multivariate models showing the effect of additional household members on the likelihood of an adolescent's school enrollment, Bangladesh, 1992 and 1995

\begin{tabular}{lccccc}
\hline \multirow{2}{*}{$\begin{array}{l}\text { Household } \\
\text { composition }\end{array}$} & \multicolumn{2}{c}{ Girls 11-19 } & & \multicolumn{2}{c}{ Boys 11-19 } \\
\cline { 2 - 3 } \cline { 5 - 6 } & $\mathbf{1 9 9 2}$ & $\mathbf{1 9 9 5}$ & & $\mathbf{1 9 9 2}$ & $\mathbf{1 9 9 5}$ \\
\hline Girls aged 6-10 & 0.67 & 0.82 & & 0.89 & $0.31^{* *}$ \\
Girls aged 11-19 & 2.18 & 1.15 & & 1.18 & 0.58 \\
Boys aged 6-10 & $0.34^{*}$ & 0.73 & & 0.75 & 0.58 \\
Boys aged 11-19 & $2.64^{* *}$ & 1.42 & & 0.85 & $0.55^{*}$ \\
Adult men & 0.62 & 0.82 & & 1.04 & 1.55 \\
Adult women & $2.59^{*}$ & $3.73^{* * *}$ & & 2.10 & $2.99^{*}$ \\
$(\mathrm{~N})$ & $(78)$ & $(92)$ & & $(90)$ & $(104)$ \\
\hline
\end{tabular}

*Significant at $\mathrm{p}<0.10 ; * * \mathrm{p}<0.05 ; * * * \mathrm{p}<0.01$.

Note: The dependent variable is equal to one if adolescent reported any time spent on school activities.

tional sister aged six to ten reduced the probability that the boy would spend time on schooling activities by 69 percent. This effect was statistically significant at the 5 percent level. Each sister aged 11 to 19 reduced the probability that a boy aged 11 to 19 would participate in schooling activities by 42 percent, and the effect was close to statistical significance. The probability that a boy aged 11 to 19 would report schooling activities also was negatively affected by the number of his brothers aged 11 to 19 , and the effect was statistically significant at the 10 percent level. For girls aged 11 to 19 in 1992, the number of brothers aged six to ten had a statistically significant negative effect on the probability that a girl reported any time in school activity, with each brother aged six to ten lowering the probability that a girl aged 11 to 19 would spend time on schooling activities by 66 percent. The number of older brothers had a statistically significant positive effect on the probability that a girl would be in school, possibly because of income effects. Adolescent boys increase the household's expectations of income. Sisters aged 11 to 19 had a strong positive effect on schooling activities, probably because with more sisters, more people in the household could do the required housework, and the effect was close to statistical significance. By 1995, as a result of the schooling incentive programs, the number of brothers and sisters in each age group did not significantly affect whether girls aged 11 to 19 spent time on schooling activities. The results suggest that because of the schooling incen- 
tive programs, the number of siblings in the household became a constraint to school attendance for boys aged 11 to 19, whereas the programs relieved household constraints for girls aged 11 to 19. As has been shown, sending adolescent sons to school required a bigger financial outlay than did sending adolescent daughters.

\section{Compatibility of Schooling with Other Work}

Because the work that girls and boys do in Bangladesh is divided strictly on gender lines, the nature of the work may explain why girls are spending more time in school than boys are. ${ }^{16}$ Table 10 shows that girls' housework is more compatible with school-

Table 10 Number of hours that girls report they spend performing housework and that boys report they spend performing wage work, by age group, according to whether they attend school, Bangladesh, 1992, 1995, and 1996

\begin{tabular}{|c|c|c|c|c|c|c|}
\hline \multirow[t]{2}{*}{ Age } & \multicolumn{2}{|c|}{$\begin{array}{c}\text { August } \\
1992\end{array}$} & $\begin{array}{c}\text { August } \\
1995 \\
\end{array}$ & \multicolumn{2}{|c|}{$\begin{array}{l}\text { May } \\
1992\end{array}$} & $\begin{array}{l}\text { May } \\
1996\end{array}$ \\
\hline & \multicolumn{6}{|c|}{ Girls (nonstudents) } \\
\hline $6-10(\mathrm{~N})$ & 0.19 & (16) & $2.75 \quad$ (7) & 0.74 & (15) & $1.01 \quad(12)$ \\
\hline \multirow[t]{2}{*}{$11-19(\mathrm{~N})$} & 4.31 & (46) & $4.39 \quad(48)$ & 4.19 & (52) & $4.30 \quad(40)$ \\
\hline & \multicolumn{6}{|c|}{ Girls (students) } \\
\hline $6-10(\mathrm{~N})$ & 0.32 & (35) & $0.55 \quad(47)$ & 0.46 & (37) & $0.48 \quad(31)$ \\
\hline \multirow[t]{2}{*}{$11-19(\mathrm{~N})$} & 1.31 & (35) & $0.96 \quad(45)$ & 1.49 & (37) & $1.12(56)$ \\
\hline & \multicolumn{6}{|c|}{ Boys (nonstudents) } \\
\hline $6-10(\mathrm{~N})$ & 0.06 & (30) & $1.26 \quad(17)$ & 0.25 & (28) & $0.00 \quad(16)$ \\
\hline \multirow[t]{2}{*}{$11-19(\mathrm{~N})$} & 0.96 & (30) & $1.82 \quad(48)$ & 1.99 & $(50)$ & $2.44 \quad(50)$ \\
\hline & \multicolumn{6}{|c|}{ Boys (students) } \\
\hline $6-10(\mathrm{~N})$ & 0.00 & (26) & $0.00 \quad(40)$ & 0.19 & (31) & $0.00 \quad(36)$ \\
\hline \multirow[t]{2}{*}{$11-19(\mathrm{~N})$} & 0.00 & $(40)$ & $0.02 \quad(55)$ & 0.00 & (49) & $0.85 \quad(49)$ \\
\hline & \multicolumn{6}{|c|}{ All boys reporting wage work } \\
\hline $6-10(\mathrm{~N})$ & 7.00 & (1) & 19.00 & 3.54 & (4) & - \\
\hline $11-19(\mathrm{~N})$ & 6.67 & (7) & $8.02 \quad(11)$ & 7.39 & (13) & $8.13 \quad(20)$ \\
\hline
\end{tabular}

- = Not applicable. 
ing than is boys' wage work. Girls who attend school also spend some time performing housework, although they do less housework than girls do who are not in school. Boys who attend school rarely report any time spent in wage work. Boys might be at a greater disadvantage attending school than girls are because of boys' better work opportunities.

Girls aged six to ten who were not attending school increased their time spent performing housework, especially between 1992 and 1995, when the amount of their time so spent increased by two and a half hours. Fewer girls were out of school by 1995 . Those girls whose parents did not respond to the schooling incentive programs are girls who probably would have spent long hours working at home whether a schooling incentive program existed or not. Girls aged 11 to 19 who were not in school increased the time they spent doing housework by very little-about six minutes. Girls aged six to ten who attended school increased the time they spent at housework slightly. Girls aged 11 to 19 who attended school decreased the time they spent performing household chores by about 20 minutes. Therefore, the time girls aged 11 to 19 spent working did not decrease by as much as the time they spent on schooling activities increased; no one-to-one relationship exists between time spent on schooling activities and time spent at housework.

A comparison of the data for August 1992 with those for August 1995 and of those for May 1992 with those for May 1996 shows that boys aged 11 to 19 who did not attend school increased their time spent doing wage work. The bottom panel of the table shows that boys who report any hours of wage work are working long hours. Small numbers of boys aged six to ten work in wage labor, but they report very long days. The data for boys aged 11 to 19 is more reliable because more observations are available. The hours worked by boys aged 11 to 19 who reported any wage work increased from 6.67 in August 1992 to 8.02 in August 1995 and from 7.39 in May 1992 to 8.13 in May 1996. This increase in wage work might explain why boys aged 11 to 19 did not increase their time spent in schooling activities by as much as did their sisters and younger brothers.

Marital status is the principal determinant of how adolescent girls spend their time. Table 11 shows that married girls spend negligible time studying or attending school. All of the increase in average hours spent in school for girls aged 11 to 19 is due to increased time that unmarried girls spent in school. The average hours of housework performed by single girls decreased as a result of the schooling incentive programs. For married girls aged 11 to 19 , the time spent at housework also decreased by about 12 
Table 11 Average number of hours spent in school and in housework by girls aged 1119, by marital status, Bangladesh, 1992, 1995, and 1996

\begin{tabular}{lccccccccc}
$\begin{array}{l}\text { Hours spent in } \\
\text { school/housework }\end{array}$ & August 1992 & \multicolumn{1}{c}{ August 1995 } & May 1992 & May 1996 \\
\hline $\begin{array}{l}\text { School } \\
\quad \text { Single }\end{array}$ & 2.92 & $(62)$ & 3.73 & $(67)$ & 2.53 & $(72)$ & 4.24 & $(77)$ \\
$\quad$ Married & 0.00 & $(19)$ & 0.02 & $(21)$ & 0.00 & $(17)$ & 0.00 & $(17)$ \\
Housework & & & & & & & & \\
$\quad$ Single & 2.06 & $(62)$ & 1.75 & $(67)$ & 2.30 & $(72)$ & 1.75 & $(77)$ \\
$\quad$ Married & 6.18 & $(19)$ & 5.97 & $(21)$ & 6.24 & $(17)$ & 5.92 & $(17)$ \\
\hline
\end{tabular}

minutes when data for 1992 are compared with those for 1995 and by about half an hour when 1992 data are compared with those for 1996. Therefore, the increase in schooling opportunities for young unmarried girls apparently did not come at the expense of the leisure time of adolescent married girls.

As shown above in Table 1, time-use patterns vary considerably for girls who are in school, depending upon the needs of the household. Girls who are out of school tend to spend considerably more hours working and especially long hours performing housework if they are married. Even among girls who are in school, however, some girls do a great deal of housework, whereas other girls do little work in addition to their school activities. Orshida's day, shown in column 1 of Table 1, represents a typical day for someone who attends school but also helps with housework and child care. Banu and Aisha, shown in columns 2 and 3 , spent time studying during the evening, but did not go to school on the day the time-use data were collected. Aisha did a considerable amount of work tending goats, but Banu did little except eat, rest, and study. Aisha and Sorzia (column 4) differ only in that Sorzia is not enrolled in school; they spent their time in similar ways, except that Sorzia spent no time studying and rested more than Aisha. Monowara's day (column 5) is by far the busiest. She is married and appears to spend most of her waking hours doing housework. The five work profiles together with the data shown in Table 11 suggest that marital status is a more important determinant of time use than is school attendance. Married women perform a considerable amount of household work, while unmarried girls perform much less. 


\section{Time Allocation of Adults}

How did adults respond to the increase in children's time spent in school? Table 12 shows the average hours adult men and women spent in agricultural work, housework, and wage work in May and August 1992, August 1995, and May 1996. Men and women are divided into two age groups, ages 20 to 29 and 30 and older. ${ }^{17}$

With the exception of women aged 20 to 29 in a comparison of data for 1992 and those for 1996, women increased their agricultural work, although they still spent less time than men did at this kind of labor. During the peak farming season, May 1992 compared with May 1996, men reduced their time spent in agricultural work.

Women did not increase their hours spent in housework in response to girls' increased time spent in school and reduced time spent performing housework. From May 1992 to May 1996, women aged 30 and older increased their hours spent doing housework by only about ten minutes. The data suggest that women increased their efficiency at performing housework. Taking the average number of hours spent at housework over the entire sample, the average time per person spent in housework decreased from 2.14 hours in August 1992 to 1.88 hours in August 1995, a decline of 12 percent (not shown). Average hours per person spent in housework increased slightly (2 percent) from 2.22 hours in May 1992 to 2.27 hours in May 1996 (not shown).

Examining changes in the time that men spent doing wage work helps in distinguishing whether boys aged 11 to 19 spent more time doing wage work because labor-market opportunities increased or because schooling incentives favored girls. The study team found little evidence that wages increased, but job opportunities may have improved, and wages are measured with error. ${ }^{18}$ If boys aged 11 to 19 responded to improved opportunities in the wage-labor market, then men should have increased their hours spent doing wage work as well. Men aged 30 and older in fact decreased their time spent doing wage work. The evidence is mixed for men in their prime working years, ages 20 to 29. A comparison of data for May 1992 with those for May 1996 suggests that the increase in the time boys aged 11 to 19 spent doing wage work was apparently not due to increases in wages, because men aged 20 to 29 increased their time spent doing wage work by only about four minutes. When August 1992 data are compared with those for August 1995, however, men aged 20 to 29 increased 
Table 12 Among adults in households with at least one child of school age, average hours spent performing agricultural work, housework, and wage work, by age and sex, Bangladesh, 1992, 1995, and 1996

\begin{tabular}{|c|c|c|c|c|c|c|}
\hline Age & & Women & & & Men & \\
\hline & & & Agricu & ural work & & \\
\hline & $\begin{array}{c}\text { August } \\
1992 \\
\end{array}$ & $\begin{array}{c}\text { August } \\
1995 \\
\end{array}$ & $\begin{array}{l}\text { Percent } \\
\text { change }\end{array}$ & $\begin{array}{c}\text { August } \\
1992 \\
\end{array}$ & $\begin{array}{c}\text { August } \\
1995 \\
\end{array}$ & $\begin{array}{l}\text { Percent } \\
\text { change }\end{array}$ \\
\hline $20-29(\mathrm{~N})$ & $0.69 \quad(53)$ & $0.93 \quad(65)$ & 35 & $2.92 \quad(50)$ & $2.41 \quad(64)$ & -18 \\
\hline $30+(\mathrm{N})$ & 0.93 (132) & 1.69 (132) & 82 & $2.35(138)$ & $2.86(142)$ & 22 \\
\hline & $\begin{array}{l}\text { May } \\
1992 \\
\end{array}$ & $\begin{array}{l}\text { May } \\
1996 \\
\end{array}$ & $\begin{array}{l}\text { Percent } \\
\text { change }\end{array}$ & $\begin{array}{l}\text { May } \\
1992 \\
\end{array}$ & $\begin{array}{l}\text { May } \\
1996 \\
\end{array}$ & $\begin{array}{l}\text { Percent } \\
\text { change }\end{array}$ \\
\hline $20-29(\mathrm{~N})$ & $0.86 \quad(50)$ & $0.68 \quad(55)$ & -21 & $3.87 \quad(54)$ & $2.27 \quad(50)$ & -41 \\
\hline $30+(\mathrm{N})$ & 1.07 (126) & $1.26(133)$ & 18 & 3.66 (136) & $2.50(144)$ & -32 \\
\hline & & & Hol & ework & & \\
\hline & $\begin{array}{c}\text { August } \\
1992 \\
\end{array}$ & $\begin{array}{c}\text { August } \\
1995 \\
\end{array}$ & $\begin{array}{l}\text { Percent } \\
\text { change }\end{array}$ & $\begin{array}{c}\text { August } \\
1992 \\
\end{array}$ & $\begin{array}{c}\text { August } \\
1995 \\
\end{array}$ & $\begin{array}{l}\text { Percent } \\
\text { change }\end{array}$ \\
\hline $20-29(\mathrm{~N})$ & $6.32 \quad(53)$ & $5.76 \quad(65)$ & -9 & $0.05 \quad(50)$ & $0.16 \quad(64)$ & 220 \\
\hline $30+(\mathrm{N})$ & $5.03(132)$ & $4.35(132)$ & -14 & $0.15(138)$ & $0.25(142)$ & 67 \\
\hline & $\begin{array}{l}\text { May } \\
1992 \\
\end{array}$ & $\begin{array}{l}\text { May } \\
1996 \\
\end{array}$ & $\begin{array}{l}\text { Percent } \\
\text { change }\end{array}$ & $\begin{array}{l}\text { May } \\
1992 \\
\end{array}$ & $\begin{array}{l}\text { May } \\
1996 \\
\end{array}$ & $\begin{array}{l}\text { Percent } \\
\text { change }\end{array}$ \\
\hline 20-29 (N) & $6.53 \quad(50)$ & $6.33 \quad(55)$ & -3 & $0.11 \quad(54)$ & $0.22 \quad(50)$ & 100 \\
\hline $30+(\mathrm{N})$ & $5.65(126)$ & $5.79(133)$ & 2 & 0.07 (136) & $0.29(144)$ & 314 \\
\hline & & & Wa & work & & \\
\hline & $\begin{array}{c}\text { August } \\
1992 \\
\end{array}$ & $\begin{array}{c}\text { August } \\
1995 \\
\end{array}$ & $\begin{array}{l}\text { Percent } \\
\text { change }\end{array}$ & $\begin{array}{c}\text { August } \\
1992 \\
\end{array}$ & $\begin{array}{c}\text { August } \\
1995 \\
\end{array}$ & $\begin{array}{l}\text { Percent } \\
\text { change }\end{array}$ \\
\hline $20-29(\mathrm{~N})$ & $0.08 \quad(53)$ & $0.20 \quad(65)$ & 150 & $1.86 \quad(50)$ & $3.25 \quad(64)$ & 75 \\
\hline $30+(\mathrm{N})$ & 0.19 (132) & $0.29(132)$ & 53 & $3.44(138)$ & $2.49(142)$ & -28 \\
\hline & $\begin{array}{l}\text { May } \\
1992 \\
\end{array}$ & $\begin{array}{l}\text { May } \\
1996 \\
\end{array}$ & $\begin{array}{l}\text { Percent } \\
\text { change }\end{array}$ & $\begin{array}{l}\text { May } \\
1992 \\
\end{array}$ & $\begin{array}{l}\text { May } \\
1996 \\
\end{array}$ & $\begin{array}{l}\text { Percent } \\
\text { change }\end{array}$ \\
\hline 20-29 (N) & $0.20 \quad(50)$ & $0.49 \quad(55)$ & 145 & $1.86 \quad(54)$ & $1.93 \quad(54)$ & 4 \\
\hline $30+(\mathrm{N})$ & 0.33 (126) & 0.15 & -55 & 3.00 (136) & $2.90(144)$ & -3 \\
\hline
\end{tabular}


their hours spent in wage work by a higher percentage than did boys aged 11 to 19 . Again, the May comparisons reflect time allocation during the peak season for agricultural work.

\section{DISCUSSION AND CONCLUSIONS}

In 1994, Bangladesh experimented with a set of ambitious and innovative interventions to increase school attendance. In the present analysis, time-use data from villages in northern Rajshahi District before and after the programs went into effect are used to assess the impact of the educational interventions on household time allocation. Although the analysis is constrained by the research design and by small samples, the data allow us to gain insights into how households adjusted their time-allocation strategies in response to the introduction of the schooling programs.

The average time that children spent in school increased as a result of the programs. Because the programs have strict attendance requirements, this finding is not surprising. The data also reveal, however, that the overall time these children spent in school is low even for those who attend school regularly. The short school day and terms of Bangladeshi schools have been a matter of concern in policy circles because they limit opportunities for learning (Lowell and Fatema 1989). Parents may have responded so well to the incentives because school attendance required so little time, however. Most children are able to attend school while contributing to household labor, particularly if they perform housework. In this respect, the findings of this study agree with those of Ravallion and Wodon (1999), who concluded that child labor is not a significant constraint to increasing children's enrollment in school in Bangladesh. Adolescent boys who do wage work are not able to attend school, however. On the other hand, only 20 percent of boys aged 11 to 19 engage in wage work. An unintended consequence of better labor-market conditions might be that boys withdraw from school. Therefore, the time-allocation patterns show that wage work is not compatible with schooling but that most other forms of household contribution are.

The amount of financial incentive for schooling is high compared with levels of income for the entire household and is probably an important reason why households respond positively to incentive programs. The impact varies by gender and age group because of the way the government targeted the program. Evidence suggests that par- 
ents are delaying the marriage of daughters aged 11 to 19 in response to the secondaryschool scholarship program. Analysis that ignores the age-heaping problem (not shown) suggests that the delay in marriage is concentrated among girls aged 11 to 15 rather than among older girls. Parents experience conflict when deciding whether to educate daughters because of the high dowries required for educated daughters in the marriage market. The gains in female education may stall because of this conflict, and how increases in girls' education will affect the marriage market is an important topic for future research.

The schooling incentive programs have had impacts on other household members, primarily on adolescent boys. Gains in schooling for unmarried girls do not seem to have come at the expense of other female household members. Evidence suggests overall improvements in the time allocation of labor in response to the school interventions, because less time is spent performing housework overall. Although boys are spending less time in school, implying a net loss for them in terms of opportunities for learning, the fact that they are spending more time engaged in wage work may be another indicator of more efficient time allocation in the short run. Adolescent boys and young men command the highest wages in these villages, because most of the wage labor is in agriculture. Although some of the schooling incentives are designed to correct gender disparities in educational opportunities, the substitution of labor for education among adolescent boys is unanticipated. With respect to their sons' education, parents might not be taking into account the long-run benefits of schooling in exchange for a short-run gain. The schooling incentive programs encourage parents to consider the social benefits of education for their secondary-school-aged daughters, but not for their sons of the same age. Is it bad policy to provide schooling programs to girls that give them benefits not offered to boys? Schultz (1998) makes a strong argument that governments should favor girls when investing in education because social returns, in terms of child health and fertility, are higher from girls' than from boys' education. Ideally, both girls and boys should be encouraged to attend school. When resources to spend on schooling are limited, targeting the resources to girls makes sense in terms of promoting gender equity. Such programs redress longstanding familial biases, and the preferential treatment of girls under this program is fully justified, at least in the short run, until gender equality is achieved in educational attainment. 


\section{APPENDIX}

\section{Data Collection}

The data used in this study have a small sample size, because collecting 24-hour recall data is extremely time intensive. Interviewers needed approximately one hour to collect time diaries each time they visited a household. At the end of each day, interviewers were required to report to the supervisors with completed forms to ensure that the visits were conducted at approximately the same time of day for all households. The supervisors frequently revisited sample households and cross-checked the forms to ensure quality. Whereas village residents collected the time-use data, the supervisors were postgraduate-level recruits from Bangladeshi universities who lived in the villages for more than a year during the study. Data coding, entry, and checking required approximately eight hours per round per household.

\section{Absences, Attrition, and Nonresponse}

In 1992, the researchers took a complete census of the study villages and selected the sample for the time-use surveys. A second census was conducted in 1995. For the 1992 time-use data, the 1992 census is used to calculate weights. The 1995 census is used to calculate weights for the 1995 and 1996 time-use data. Because the time-use data are longitudinal, the 1995 census is used to examine the sample attrition that occurred between 1992 and 1995 and between 1995 and 1996. Statistics presented in the paper that are derived from the time-allocation data use the weights, which control for oversampling of female-headed households and sample attrition. The 1995 and 1996 time-use data did not include the gender of the respondents; therefore, the time-use data were matched with the 1995 census data to obtain variables such as gender and marital status. Some attrition occurred between the 1995 census and collection of the 1995 timeallocation data.

For example, in 1992, all of the individuals living in female-headed households were included in the sample, along with 25 percent of the individuals living in maleheaded households (a total of 28 percent of all households). Comparing the 1995 timeuse data with the 1995 census, 48 percent of individuals living in female-headed house- 
holds and 21 percent of the individuals living in male-headed households were included in the sample (a total of 24 percent). Comparing 1996 time-use data with the 1995 census, 47 percent of individuals living in female-headed households in 1995 and 21 percent of the individuals living in male-headed households were included in the sample (a total of 23 percent). Therefore, by 1995 and 1996, the households chosen for the sample in 1992 no longer included all of the female-headed households. In the village, households were unstable as headship moved from female headship to male headship and vice versa.

Because observations concerning people who were absent were excluded when the data were collected, the time children spent on schooling activities might be overstated. If the pattern of absences is the same for data collected in 1995 and 1996 as it was for data collected in 1992, then the change in the time spent on schooling activities will not be biased.

For adolescent girls, the main reason for absence was attrition. When girls are married, they leave their natal household and move into their husbands' households. Unless girls in the sample marry into households that happen to be included in the sample, they are dropped from the sample. Once a girl is married, she is unlikely to continue her schooling. If girls marry out of the household at a faster rate than their older brothers marry and bring their young wives into the household, over time the proportion of adolescent girls in the population will decline. For example, considering girls aged 11 to 19 , if girls move out when they get married, those who remain in the sample will be a select group. The girls who remain are more likely to be from families that are not as eager to marry their daughters off at a young age than are the girls who have left the sample. These families are also more likely than average to value female education and may be keeping their daughters at home in order to further their education. Unfortunately, the 1996 data do not reveal whether a person has no valid time allocation because he or she was absent on the day the data were recorded or because he or she has left the village permanently.

Boys' absences will also tend to bias the average hours of schooling upward and the average hours of wage work downward. Time-allocation data are missing for adolescent boys because of seasonal migration. Men and adolescent boys travel to agricultural surplus areas for short periods of time for harvest wage work. A less likely reason 
for absences is that boys may be attending university. Given the typical ages for school completion, this possibility will probably affect men above the age of 20 .

If the rates of village in-migration and out-migration were the same in August 1992 and August 1995 and again in May 1992 and May 1996, a direct comparison of the two time periods will give an unbiased sense of how the average hours spent in school, agricultural activities, housework, and wage work have changed because of the incentive program. Figures A1 to A4 compare the sample age distributions at two points in time for females and males. Figures A1 and A2 show that when data for August 1992 is compared with those for August 1995 and those for May 1992 with those for May 1996 the age distribution in the two later years showed a higher proportion of girls aged 11 to 19 , and a smaller proportion of women aged 20 to 29 . The increased proportion of girls aged 11 to 19 occurred because they were less likely to be married, and thus to have left the villages, in 1995 and 1996 than in 1992. They also indicate that the observed changes in average schooling hours are not due to increased selectivity of girls who remain in the village.

In general, girls and women were more successfully interviewed in the time-use surveys because they are less mobile than men, but there were two exceptions. The girls

Figure A1 Age distribution of females in the sample having valid time-allocation data, Bangladesh, August 1992 and August 1995

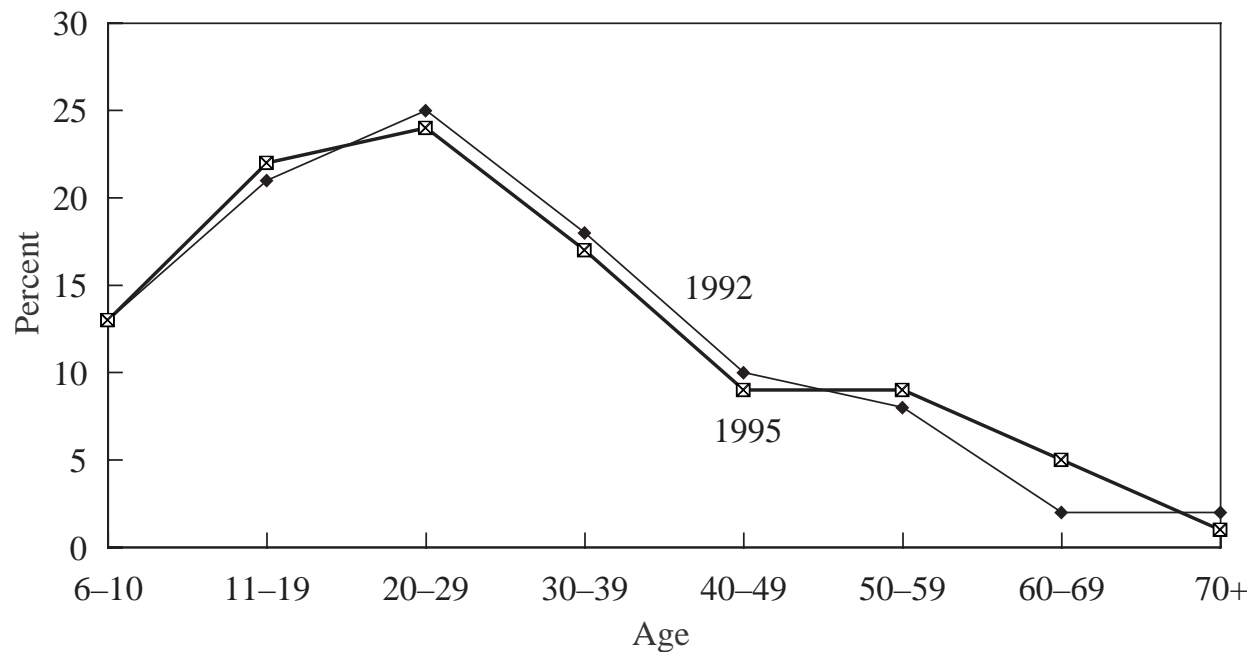


Figure A2 Age distribution of females in the sample with valid time-allocation data, Bangladesh, May 1992 and May 1996

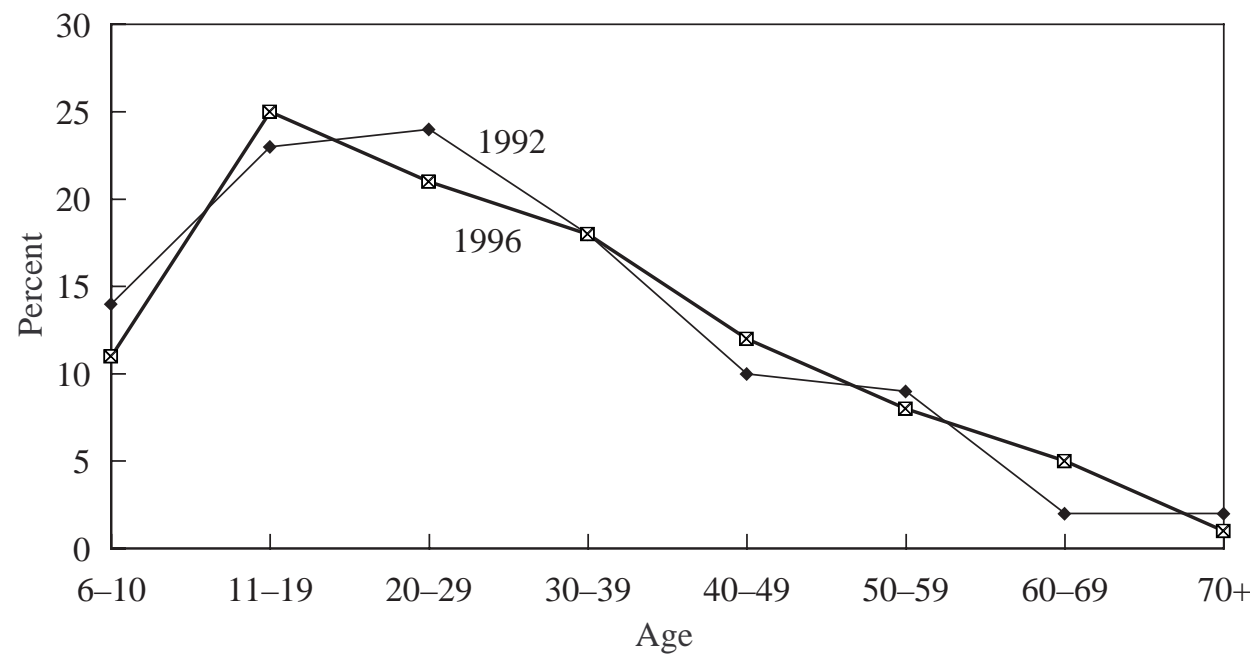

Figure A3 Age distribution of males in the sample with valid timeallocation data, Bangladesh, August 1992 and August 1995

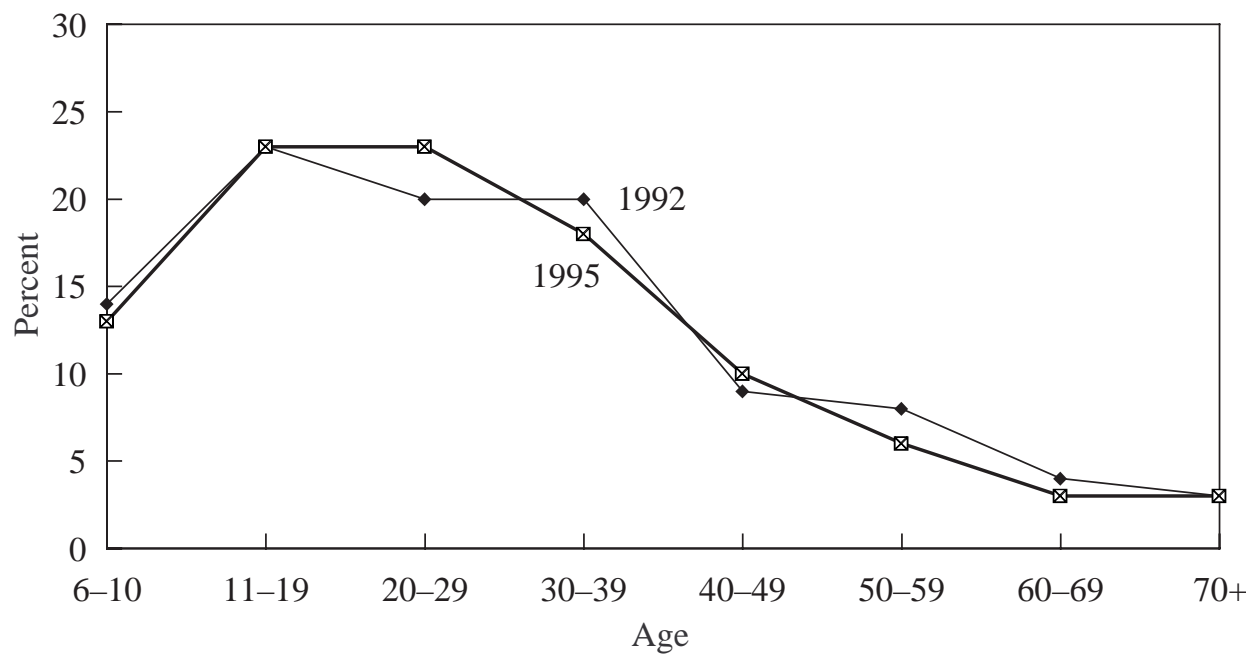


Figure A4 Age distribution of males in the sample with valid time-allocation data, Bangladesh, May 1992 and May 1996

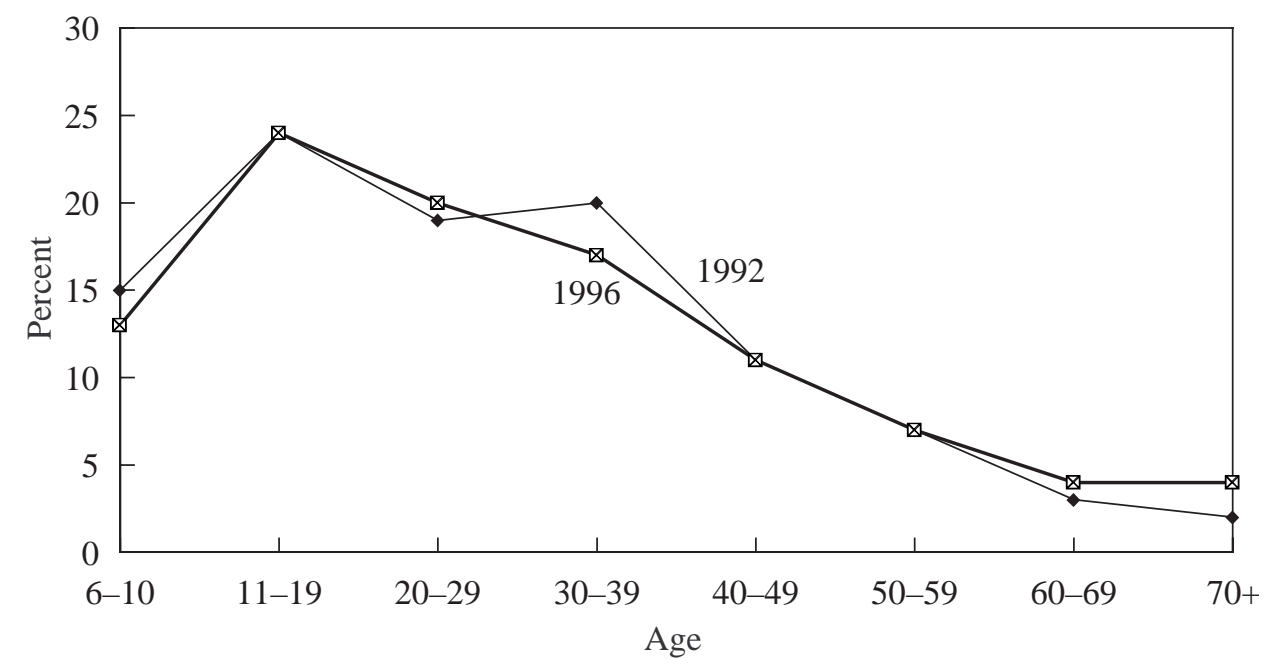

in the youngest age group, ages six to ten, were reluctant to respond to the time-use questions. As a result, the proportion of girls aged six to ten in the sample was lower in 1996 than in 1992: 13 percent of these girls were absent in 1996, compared with only 2 percent absent in 1992. In 1996, the time-use data collection coincided with another survey for which the children were interviewed directly. Many of them refused to be interviewed and only responded after a considerable amount of coaxing and cajoling. Although the time-use survey was separate, the survey interview may have caused a considerable amount of anxiety because children are unused to being respondents.

The proportion of women aged 20 to 29 was also lower in May 1996 than in May 1992, with an absence rate of 9 percent in 1992 and 13 percent in 1996. These absences may have been related to their permanent departure from the village as a result of marriage. Observations in the field during the survey suggest that reluctance to respond and temporary migration are unlikely explanations for absences in this category of young women.

As shown in Figures A3 and A4, for males, the proportion of boys aged six to ten with valid time-allocation data was lower in 1995 and 1996 than in 1992. The proportion of boys aged 11 to 19 stayed constant in a comparison of 1992 with 1995 and of 1992 with 1996. The proportion of men aged 20 to 29 was also higher in 1995 and 1996 than in 1992. 


\section{Notes}

1. A complete description of the village communities and of the schooling incentive programs is given in Amin and Sedgh (1998).

2. The taka-to-dollar conversion in 1992 was approximately US $\$ 1=$ Tk.38.

3. The value of the wheat payments fluctuates during the year, being especially valuable in the months before the harvest. Data collected on economic transactions in 1991-92 showed that the price of wheat varies over the year from 5.5 taka to 10 taka per kilogram.

4. According to the 1993-94 Demographic and Health Survey (Mitra et al. 1994), this was the median age at marriage for women currently aged 20-24.

5. BRAC schools do not have desks and chairs; instead of pencils and paper, the children sit on the floor and use small slates and chalk for writing their lessons.

6. Note that in Figure 1, girls' secondary-school fees are not equal to zero. In 1996, scholarships were not yet available for eighth grade. Also, girls might have paid fees and later have been reimbursed for them. Unfortunately, these expenditures cannot be sorted out completely.

7. The book expenditures include costs for books not necessarily used for class.

8. For example, at age 12, total expenditures are two times higher for boys in school than for those who are not in school. Expenditures for girls in school are about 50 percent higher than they are for those not in school. Despite the school programs' being aimed at poor children, those enrolled in school are likely to come from comparatively wealthy families, however, so that the results reflect an income effect.

9. The households were visited every 15 days throughout the year, but in the second half of the study, interviewers directly observed household activities on alternate rounds only. These data were used to verify the validity of the 24-hour recall method, but they are not included in the present analysis. 
10. In the time-allocation problem, the marginal utility obtained from a good produced in the household is set equal to its shadow price. The shadow price is endogenous, because it depends on the hours spent by household members in producing the good, as well as on household preferences, income, and wages. For home-produced goods, no close substitutes exist in the market that can provide a market price. Contrast this situation with a traditional labor-supply model for men, where the wage is determined by a market and is not a function of all the variables that might affect a household's consumption. This problem could be resolved by using variables that affect each household member's time allocation without affecting that of other members. Such variables are difficult to imagine, let alone to be found in the data set.

11. Solberg and Wong (1992) worked out mathematically how changes in wages and income might affect time-allocation decisions (market, home, and leisure), and showed that the effects of an increase in the husband's wage on the wife's time allocation is ambiguous, as is the effect of changes in the wife's wage on the husband's time allocation. The only unambiguous effect occurs when a wife's wage increases, and consequently she spends less time working at home. An increase in unearned income should increase time spent in leisure, decrease time spent in the market, and leave time spent at home unchanged for both husbands and wives.

12. The censuses were not greatly affected by absences, because the household members who were present answered questions about others who were absent. Also, interviewers returned to households to follow up on missing information.

13. Unfortunately, no data are available on the length of the school day in 1992. The time-use data collected in 1992 combined time spent in the classroom with time spent studying at home.

14. Taking an average of hours for all children, whether they are enrolled in school or not, shows that children spend about equal amounts of time in the classroom and studying at home. 
15. When examining hours by grade level, sample sizes do not match perfectly with the analyses that examine hours by age groups. In 1996, the data set that included information about grade level used a slightly different sample than did the timeuse data set. Therefore, the data sets must be made to match, with the result that 17 cases are lost.

16. For discussion of how work in Bangladesh is strictly divided along gender lines, see Amin (1997).

17. Originally, men and women were divided into more age categories, but the results are easier to interpret when only two age groups are presented. Again, the small sample sizes created problems. Adults aged 20 to 29 are most likely to be increasing their time at work in response to the increase in their children's time at school. Labor of adults aged 20 to 29 is a closer substitute for children's work than the labor of adults aged 30 and older. Adults aged 20 to 29 also constitute a control group for adolescents.

18. Data on wage rates are difficult to obtain and subject to error because much of men's wage compensation consists of meals taken on the job and other payment in kind (Rai and Topa 1997).

\section{References}

Amin, Sajeda. 1997. "Poverty-purdah trap in rural Bangladesh: Implications for women's roles in the family," Development and Change 28(2):213-233.

Amin, Sajeda and Gilda Sedgh. 1998. "Incentive Schemes for School Attendance in Rural Bangladesh," Policy Research Division Working Paper No. 106. New York: Population Council.

Becker, Gary. 1965. “A theory of the allocation of time," The Economic Journal 75(299): 493-517.

Cain, Mead. 1977. "The economic activities of children in a village in Bangladesh," Population and Development Review 3(3): 201-227. 
Khandker, Shahidur, Hussain A. Samad, and Zahed H. Khan. 1998 "Income and employment effects of microcredit programmes: Village-level evidence from Bangladesh," Journal of Development Studies 35(2): 96-124.

Lowell, Catherine and Kaniz Fatema. 1989. The BRAC Non-formal Primary Education Program in Bangladesh. New York: UNICEF.

Mitra, S.N., M. Nawab Ali, Shahidul Islam, Anne R. Cross, and Tulshi Saha. 1994. Bangladesh Demographic and Health Survey 1993-1994. Dhaka: National Institute of Population Research and Training.

Mitra, S.N., Ahmed Al-Sabir, Anne R. Cross, and Kanta Jamil. 1997. Bangladesh Demographic and Health Survey 1996-97. Dhaka: National Institute of Population Research and Training.

Rai, Ashok and Giorgio Topa. 1997. "Does group lending reach the vulnerable? Evidence from northern Bangladesh," paper presented at the Population Council meeting on Microcredit and Fertility, New York, 15-16 December.

Ravallion, Martin and Quentin Wodon. 1999. "Does Child Labor Displace Schooling? Evidence on Behavioral Responses to an Enrollment Subsidy." World Bank Policy Research Working Paper No. 2116. Washington, DC: The World Bank.

Schultz, T. Paul. 1998. "Why governments should invest more educating girls than boys." Yale University Economic Growth Center. Mimeograph.

Solberg, Eric and David Wong. 1992. "Family time use," Journal of Human Resources 27(3): 485-510.

Tiefenthaler, Jill. 1997. "Fertility and family time allocation in the Philippines," Рориlation and Development Review 23(2): 377-398.

United Nations Development Programme (UNDP). 1998. Human Development Report. New York: Oxford University Press. 


\title{
POLICY RESEARCH DIVISION WORKING PAPERS
}

\author{
Recent Back Issues
}

1998

*106 Sajeda Amin and Gilda Sedgh, "Incentive schemes for school attendance in rural Bangladesh."

107 Martin Brockerhoff and Paul Hewett, "Ethnicity and child mortality in sub-Saharan Africa."

108 Ann E. Biddlecom and Bolaji M. Fapohunda, "Covert contraceptive use: Prevalence, motivations, and consequences."

109 John Bongaarts and Griffith Feeney, "On the quantum and tempo of fertility."

110 Barbara S. Mensch, Daniel Bagah, Wesley H. Clark, and Fred Binka, "The changing social environment for adolescents in the Kassena-Nankana District of northern Ghana: Implications for reproductive behavior."

111 Martin Brockerhoff and Ann Biddlecom, "Migration, sexual behavior, and HIV diffusion in Kenya."

112 Zeba A. Sathar and John B. Casterline, "The onset of fertility transition in Pakistan."

113 Geoffrey McNicoll, "Government and fertility in transitional and posttransitional societies."
114 John Bongaarts, "Fertility and reproductive preferences in post-transitional societies."

115 Fiona Steele, Sajeda Amin, and Ruchira T. Naved, "The impact of an integrated micro-credit program on women's empowerment and fertility behavior in rural Bangladesh."

*116 Cynthia B. Lloyd, Barbara S. Mensch, and Wesley H. Clark, "The effects of primary-school quality on the educational participation and attainment of Kenyan girls and boys."

117 Sajeda Amin and Cynthia B. Lloyd, "Women's lives and rapid fertility decline: Some lessons from Bangladesh and Egypt."

118 James F. Phillips and Mian Bazle Hossain, "The impact of family planning household service delivery on women's status in Bangladesh."

119 Mark R. Montgomery and John B. Casterline, "Social networks and the diffusion of fertility control."

* No longer available 
*120 John Bongaarts, "The fertility impact of changes in the timing of childbearing in the developing world."

*121 James F. Phillips, Wendy L. Greene, and Elizabeth F. Jackson, "Lessons from community-based distribution of family planning in Africa."

122 Mark R. Montgomery, "Mortality decline and the demographic response: Toward a new agenda."

123 Mark R. Montgomery, Mary ArendsKuenning, and Cem Mete, "The quantity-quality transition in Asia."

124 Barbara S. Mensch, Wesley H. Clark, Cynthia B. Lloyd, and Annabel S. Erulkar, "Premarital sex and school dropout in Kenya: Can schools make a difference?"

125 John Bongaarts and Rodolfo A. Bulatao, "Completing the demographic transition."

126 Geoffrey McNicoll, "Population weights in the international order."

127 Cynthia B. Lloyd, Carol E. Kaufman, and Paul Hewett, "The spread of pri- mary schooling in sub-Saharan Africa: Implications for fertility change."

128 John B. Casterline, "The onset and pace of fertility transition: National patterns in the second half of the twentieth century."

129 Mark R. Montgomery, Michele Gragnolati, Kathleen Burke, and Edmundo Paredes, "Measuring living standards with proxy variables."

130 Bamikale Feyisetan and John B. Casterline, "Fertility preferences and contraceptive change in developing countries."

131 Martin Brockerhoff, "Urban growth in developing countries: A review of projections and predictions."

132 Omaima El-Gibaly, Barbara Ibrahim, Barbara S. Mensch, and Wesley H. Clark, "The decline of female circumcision in Egypt: Evidence and interpretation."

133 Mary Arends-Kuenning and Sajeda Amin, "The effects of schooling incentive programs on household resource allocation in Bangladesh."

* No longer available 